Original Paper http://ajol.info/index.php/ijbcs http://indexmedicus.afro.who.int

\title{
Serotypes and antibiotic susceptibility profile of encapsulated Streptococcus pneumoniae strains isolated from under five years old children
}

\author{
N. TORIMIRO ${ }^{1 *}$, A. O. FABUNMI ${ }^{1}$ and A. AJAYI ${ }^{2}$ \\ ${ }^{I}$ Department of Microbiology, Obafemi Awolowo University Ile-Ife, Nigeria. \\ ${ }^{2}$ Paediatrics Unit, Mother and Child Hospital, Akure, Nigeria. \\ ${ }^{*}$ Corresponding author; Postal Address: P.O. Box 1946, Obafemi Awolowo University Campus, Ile-Ife, \\ Nigeria; E-mail: ntorimiro@gmail.com; ntorimiro@oauife.edu.ng \\ Phone number: +2348056538728
}

\begin{abstract}
Streptococcus pneumoniae is one of the leading causes of childhood morbidity and mortality globally. The study determined the antibiotic susceptibility profile and molecular serotyping of encapsulated $S$. pneumoniae isolated from the blood of 100 under 5 years old children presented at the children's clinic of the Mother and Child Hospital Akure, Nigeria. The S. pneumoniae isolates were identified using standard microbiological techniques. Antibiotic susceptibility test included the Kirby-Bauer disc diffusion method. The detection of the strain serotypes by polymerase chain reaction (PCR) technique was conducted and the data derived from the study were statistically analysed. A total of $16(16 \%)$ encapsulated S. pneumoniae strains were identified. All the 16 isolates were resistant to penicillin, cloxacillin, tetracycline and erythromycin. The isolates were all multi-resistant to the antibiotics tested. Serotypes $6 \mathrm{~B}, 14$ and $19 \mathrm{~F}$ were detected. The study presents the baseline report of serotype 14 detection at the study centre. The continuous monitoring of serotype distribution and antibiotic susceptibility in this population will assist immensely in future preventive and treatment strategies.
\end{abstract}

(C) 2018 International Formulae Group. All rights reserved.

Keywords: S. pneumoniae, encapsulated, serotypes, blood, antibiotic resistance

\section{INTRODUCTION}

Streptococcus pneumoniae is a bacterial pathogen that is an important cause of infections among children and the elderly (O’Brien et al., 2009; Hackel et al., 2013). The diseases caused by $S$. pneumoniae range from mild respiratory tract non-invasive mucosal infections such as otitis media and sinusitis to more severe invasive diseases such as pneumonia and meningitis (HenriquesNormark and Tuomanen, 2013). Among the virulence factors of $S$. pneumoniae is the polysaccharide capsule that prevents phagocytosis by interfering with binding of complement V3b to the cell's surface by the host's immune cells (Barocchi et al., 2006; Kadioglu et al., 2011). S. pneumoniae and Haemophilus influenza have been reported to 
be the leading causes of acute respiratory infections in children in developing countries (O’Brien et al., 2009).

The organism has been observed to be the cause of childhood mortality from vaccine preventable illness especially in under five years old children worldwide (O'Brien et al., 2009; Apansia et al., 2015). In Nigeria it has been observed that $S$. pneumoniae is the cause of $13 \%$ of overall deaths in north Central Nigeria and $80 \%$ of deaths from meningitis in Ibadan both occurring in children below 5 years old (Falade et al., 2009; Obaro et al., 2011; Iwalokun et al., 2012). The risk factors for invasive pneumococcal disease (IPD) in Nigeria identified includes air pollution overcrowding nasopharyngeal carriage and high level transmission of the pathogen as well as the presence of co-morbidities such as HIV/AIDS and sickle cell anaemia (Adetifa et al., 2012).

Of all the ninety-one pneumococcal serotypes that have been described, only 46 have been categorised into serogroups based on their immunological cross-reactivity and not all have been observed to cause diseases (Hausdroff et al., 2000; Shouval et al., 2006: Park et al., 2007). Reports have shown that not all virulent serotypes and majority of antibiotic resistant strains have been covered in the conjugate vaccines in use (Nuorti et al., 2010; Gant et al., 2012; Pichon et al., 2013).

The emergence of multiple antibiotic resistant strains has been observed to complicate the management of infections caused by $S$. pneumoniae (Beekman et al., 2005). It has been reported that there is a correlation between serotypes and antimicrobial resistance (Hecini-Hannachi et al., 2014). However, Link-Gelles et al. (2013) suggested selective pressure from antibiotics use determines resistance patterns rather than differences in serotype distribution. The aim of the present study was to determine the effect of serotype distribution and antibiotic susceptibility pattern of $S$. pneumoniae strains isolated from paediatric population in the study centre.

\section{MATERIALS AND METHODS}

\section{Ethical clearance and samples collection}

A total of 100 under five years old children presented at the children's clinic of the Mother and Child Hospital in Akure, Nigeria were recruited for the study. All were consecutively recruited after ethical clearance and informed consent were obtained. Two $\mathrm{ml}$ venous blood were aseptically collected from each subject and transferred immediately into culture bottles containing sterile Robertson's cooked meat broth (Biomark, India) and incubated at $37{ }^{\circ} \mathrm{C}$ for $18 \mathrm{~h}$.

\section{Isolates identification}

A turbid appearance in the culture bottles indicated the growth of microorganisms. A loopful of the culture was thereafter, streaked on a sterile blood agar plate (blood base agar enriched with 5\% sheep blood). The plates were inverted and placed in a $\mathrm{CO}_{2}$ jar and incubated at $37^{\circ} \mathrm{C}$ for $24 \mathrm{~h}$. The isolates were identified as Streptococcus pneumoniae using methods such as catalase, capsule, optochin susceptibility test as described (Ruoff et al., 2003).

\section{Antibiotic susceptibility testing}

The Kirby-Bauer disc diffusion was used to test for the antibiotic susceptibility of the isolates and the isolates were standardised to 0.5 McFarland standard. The impregnated susceptibility discs of known concentrations included penicillin G (10 units), amoxicillin/clavulanic acid (2:1) (Oxoid, UK) 
while cefuroxime $(30 \mu \mathrm{g})$, gentamicin $(10 \mu \mathrm{g})$, ceftriaxone $(30 \mu \mathrm{g})$, ofloxacin $(5 \mu \mathrm{g})$, cotrimoxazole $(25 \mu \mathrm{g})$, erythromycin $(5 \mu \mathrm{g})$, tetracycline $(30 \mu \mathrm{g})$, chloramphenicol $(5 \mu \mathrm{g})$ ceftazidime $(30 \mu \mathrm{g})$. amoxicillin $(5 \mu \mathrm{g})$ and cloxacillin $(5 \mu \mathrm{g})$ (Abtek Biologicals, UK). The isolates were inoculated onto Mueller Hinton agar containing 5\% sheep blood, antibiotics disc were aseptically placed and incubated at $37{ }^{\circ} \mathrm{C}$ in a candle jar for $18 \mathrm{~h}$. The plates were thereafter, read and susceptibility was interpreted according to the approved guidelines of the CLSI for Streptococcus pneumoniae (CLSI, 2013) and AB Biodisk interpretative chart. Resistance of the isolates to three or more of the following antibiotic classes: penicillin, erythromycin, chloramphenicol, tetracycline or trimethoprim-sulfamethoxazole

(cotrimoxazole) was referred to as multi-drug resistant.

\section{Preparation of DNA template}

The DNA of the isolates was extracted as described (CDC, 2011). Bacterial colonies were suspended in $0.85 \%$ normal saline and briefly vortexed and incubated at $70{ }^{\circ} \mathrm{C}$ for 15 minutes. The suspension was subsequently centrifuged at $12000 \mathrm{x} \mathrm{g}$ for 2 minutes and the supernatant was decanted. The cells were resuspended in $50 \mu \mathrm{l}$ TE buffer containing 10 $\mu 1$ mutanolysin and $8 \mu 1$ hyaluronidase. The samples were incubated at $37{ }^{\circ} \mathrm{C}$ for $18 \mathrm{~h}$ and the suspension was boiled for 10 minutes and finally centrifuged at $12000 \mathrm{x}$ g for 4 minutes. The supernatant obtained was used as the template.

\section{Detection of the serotypes}

The serotypes 6B, 14, 7F, 9V, 18 and 19F detection with published primer sequences and polymerase chain reaction (PCR) method were done as described (CDC, 2011) and the serotype primer sequence are as shown in Table 1. The sequential PCR reactions for a $25 \mu 1$ included $0.5 \mu 1$ forward and reverse primers, PCR grade water $(17 \mu \mathrm{l})$ and taq polymerase $(5 \mu \mathrm{l})$ that made an aliquot of $23 \mu 1$. The $23 \mu 1$ master mix was aliquoted into PCR eppendorf tube and a $2 \mu 1$ of DNA lysate was added to each appropriate tube making a total of $25 \mu \mathrm{l}$ reaction. The PCR tubes were loaded in the GeneAmp PCR system 9700 thermocycler (Applied Biosystems) and the amplification and cycling steps are as described (CDC, 2011). The PCR product was electrophoresed on a $1 \%$ Tris Borate EDTA (TBE) agarose gel at $75 \mathrm{~V}$ for 60 secs. The bands were subsequently visualised under UV transilluminator and photographed with a digital camera.

Simple percentage/mean were used to present the frequency of the Streptococcus pneumoniae isolates and the antibiotics susceptibility patterns. 
Table 1: Primers used for the detection of the target genes.

\begin{tabular}{|c|c|c|c|c|c|c|c|c|c|}
\hline Primers & Primer sequence $\left(5^{1}-3^{1}\right)$ & Gene & $\mathbf{P C}(\mu \mathrm{M})$ & Bp & NOC & Denaturation & Annealing & Extension & $\begin{array}{l}\text { Reference/ } \\
\text { Source }\end{array}$ \\
\hline \multirow[t]{2}{*}{$6 \mathrm{~A} / 6 \mathrm{~B} / 6 \mathrm{C} / 6 \mathrm{D}$} & AAT TTG TAT TTT ATT CAT & & & & & & & & \\
\hline & GCC TAT ATC TGG & $w c i \mathrm{P}$ & 0.3 & 250 & 35 & $94^{\circ} \mathrm{C}$ for $30 \mathrm{~s}$ & $57^{\circ} \mathrm{C}$ for $45 \mathrm{~s}$ & $72{ }^{\circ} \mathrm{C}$ for $40 \mathrm{~s}$ & CDC, 2011 \\
\hline \multirow[t]{2}{*}{$6 \mathrm{~A} / 6 \mathrm{~B} / 6 \mathrm{C} / 6 \mathrm{D}$} & TTA GCG GAG ATA ATT & & & & & & & & \\
\hline & TAA AAT GAT GAC TA & & & & & & & & \\
\hline \multirow[t]{2}{*}{$7 \mathrm{~F} / 7 \mathrm{~A}$} & TCC AAA CTA TTA CAG & & & & & & & & \\
\hline & TGG GAA TTA CGG & Wzy & 0.4 & 559 & 35 & $94{ }^{\circ} \mathrm{C}$ for $40 \mathrm{~s}$ & $61^{\circ} \mathrm{C}$ for $60 \mathrm{~s}$ & $72{ }^{\circ} \mathrm{C}$ for $60 \mathrm{~s}$ & CDC, 2011 \\
\hline \multirow[t]{2}{*}{$7 \mathrm{~F} / 7 \mathrm{~A}$} & ATA GGA ATT GAG ATT & & & & & & & & \\
\hline & GCC AAA GCG AC & & & & & & & & \\
\hline \multirow[t]{2}{*}{$9 \mathrm{~V} / 9 \mathrm{~A}$} & GGG TTC AAA G TC AGA & & & & & & & & \\
\hline & CAG TG A ATC TTA A & $w z y$ & 0.5 & 819 & 35 & $94{ }^{\circ} \mathrm{C}$ for 40 s & $60^{\circ} \mathrm{C}$ for $45 \mathrm{~s}$ & $72{ }^{\circ} \mathrm{C}$ for $45 \mathrm{~s}$ & $\mathrm{CDC}, 2011$ \\
\hline \multirow[t]{2}{*}{$9 \mathrm{~V} / 9 \mathrm{~A}$} & CCA TGA ATG A AA TCA & & & & & & & & \\
\hline & $\begin{array}{l}\text { ACA TT G TCA GTA GC } \\
\text { GAA ATG TTA CTT GGC }\end{array}$ & & & & & & & & \\
\hline 14 & GCA GGT GTC AGA ATT & $w z y$ & 0.3 & 189 & 40 & $94{ }^{\circ} \mathrm{C}$ for $40 \mathrm{~s}$ & $58^{\circ} \mathrm{C}$ for $45 \mathrm{~s}$ & $72{ }^{\circ} \mathrm{C}$ for $45 \mathrm{~s}$ & $\mathrm{CDC}, 2011$ \\
\hline \multirow[t]{2}{*}{14} & GCC AAT ACT TCT TAG & & & & & & & & \\
\hline & TCT CTC AGA TGA AT & & & & & & & & \\
\hline \multirow[t]{2}{*}{$18 /(18 \mathrm{~A} / 18 \mathrm{~B} / 18 \mathrm{C} / 18 \mathrm{~F})$} & CTT AAT AGC TCT CAT & & & & & & & & \\
\hline & TAT TCT TTT TTT AAG CC & $w z y$ & 0.3 & 573 & 40 & $94^{\circ} \mathrm{C}$ for $60 \mathrm{~s}$ & $58^{\circ} \mathrm{C}$ for $45 \mathrm{~s}$ & $72{ }^{\circ} \mathrm{C}$ for $45 \mathrm{~s}$ & CDC, 2011 \\
\hline \multirow[t]{2}{*}{$18 /(18 \mathrm{~A} / 18 \mathrm{~B} / 18 \mathrm{C} / 18 \mathrm{~F})$} & TTA TCT GTA AAC CAT & & & & & & & & \\
\hline & ATC AGC ATC TGA AAC & & & & & & & & \\
\hline \multirow[t]{2}{*}{$19 \mathrm{~F}$} & GTT AAG ATT GCT GAT & & & & & & & & \\
\hline & CGA TTA ATT GAT ATC C & $w z y$ & 0.5 & 304 & 35 & $94{ }^{\circ} \mathrm{C}$ for $40 \mathrm{~s}$ & $58^{\circ} \mathrm{C}$ for $45 \mathrm{~s}$ & $72{ }^{\circ} \mathrm{C}$ for $45 \mathrm{~s}$ & CDC, 2011 \\
\hline \multirow[t]{2}{*}{$19 \mathrm{~F}$} & GTA ATA TGT CTT TAG & & & & & & & & \\
\hline & GGC GTT TAT GGC GAT AG & & & & & & & & \\
\hline
\end{tabular}




\section{RESULTS}

A total of $16(16 \%)$ encapsulated $S$. pneumoniae isolates were identified. All the isolates were resistant to penicillin, amoxicillin, cloxacillin, erythromycin and tetracycline, while $13(81.3 \%)$ of the isolates were resistant to cotrimoxazole. Nine $(56.3 \%)$ of the isolates were resistant to Amoxicillin/Clavulanate 2:1, ceftazidime and chloramphenicol while $7(43.3 \%)$ of the isolates were resistant to cefuroxime and 2 $(12.5 \%)$ to ceftriaxone and gentamycin. However, $15(93.8 \%)$ of the isolates were susceptible to ofloxacin as shown (Table 2).

Of the 16 isolates serotyped, eleven of the isolates were typable while 5 were non- typable. The serotypes detected were serotypes 19F which accounted for 6 of all the serotypes recovered followed by 4 isolates for serotype 6B. Serotype 14 was detected in only one of the isolates at 189bp (Figure 1).

The multiple antibiotic resistance of the 16 isolates showed that all the typable and non- typable strains were multiple antibiotic resistant. In all, the isolates were resistant to three or more classes of aantibiotics. The three serotypes were resistant to 6-12 antibiotics; one was susceptible to 4 antibiotics but six were susceptible to 5-7 antibiotics while nine isolates were resistant to $10-12$ antibiotics. It was observed that serotypes 14 and $6 \mathrm{~B}$ were resistant to 10-12 antibiotics (Figure 2).

Table 2: Profile of antibiotic susceptibility of the S. pneumoniae isolates.

\begin{tabular}{lllll}
\hline Antibiotics $(\boldsymbol{\mu g})$ & $\begin{array}{l}\text { Number } \\
\text { isolates }\end{array}$ & Susceptible & $\begin{array}{l}\text { Intermediate } \\
\text { Number }(\%)\end{array}$ & Resistant \\
\hline Amoxicillin $(25 \mu \mathrm{g})$ & & 0 & 0 & 100 \\
Amoxicillin/Clavulanate $2: 1$ & & $4(25)$ & $3(18.8)$ & $9(56.3)$ \\
Ceftazidime $(30 \mu \mathrm{g})$ & $4(25)$ & $3(18.8)$ & $9(56.3)$ \\
Ceftriaxone $(30 \mu \mathrm{g})$ & & $7(43.8)$ & $7(43.8)$ & $2(12.5)$ \\
Cefuroxime $(30 \mu \mathrm{g})$ & & $6(37.5)$ & $3(18.8)$ & $7(43.8)$ \\
Chloramphenicol $(30 \mu \mathrm{g})$ & 16 & $5(31.3)$ & $2(12.5)$ & $9(56.3)$ \\
Cloxacillin $(5 \mu \mathrm{g})$ & & 0 & 0 & 100 \\
Cotrimoxazole $(30 \mu \mathrm{g})$ & & $1(6.3)$ & $2(12.5)$ & $13(81.3)$ \\
Erythromycin $(5 \mu \mathrm{g})$ & 0 & 0 & 100 \\
Gentamycin $(10 \mu \mathrm{g})$ & & $13(81.3)$ & $1(6.3)$ & $2(12.5)$ \\
Ofloxacin $(5 \mu \mathrm{g})$ & & $15(93.8)$ & $1(6.3)$ & 0 \\
Penicillin $\mathrm{G}(10 \mathrm{units})$ & & 0 & 0 & 100 \\
Tetracycline $(30 \mu \mathrm{g})$ & & 0 & 0 & 100 \\
\hline
\end{tabular}

\section{$\begin{array}{llllllllllllllll}1 & 2 & 3 & 4 & 5 & 6 & 7 & 8 & 9 & 10 & 11 & 12 & 13 & 14 & 15 & \mathrm{M}\end{array}$}

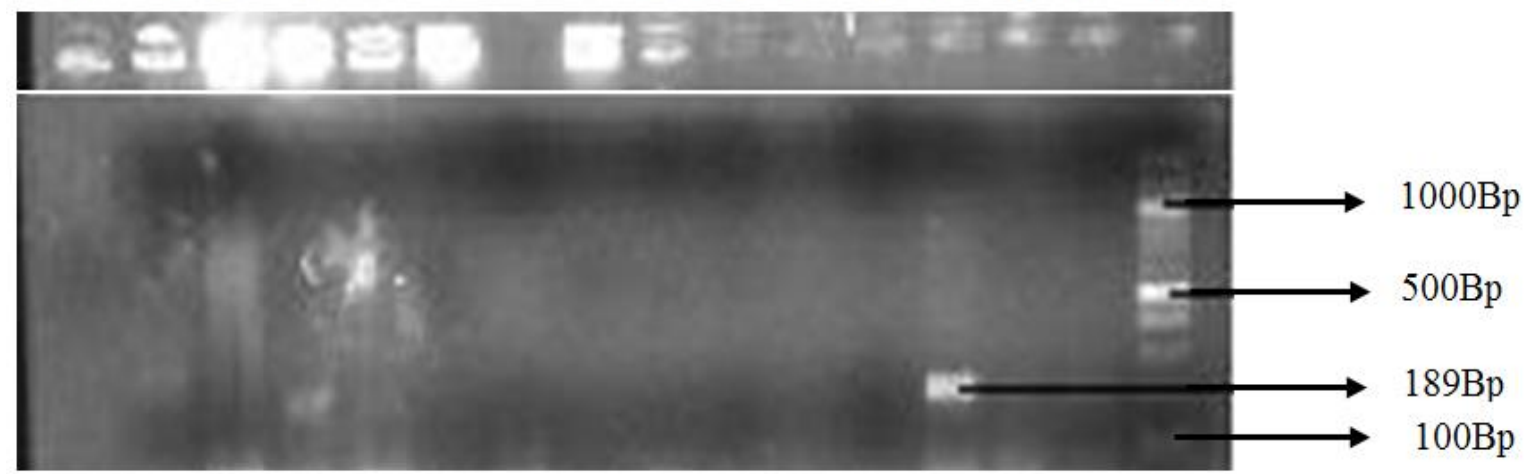

Figure 1: PCR detection of serotype 14 in S. pneumoniae isolates.

Lane 13 is positive for serotype 14 as indicated by $189 \mathrm{bp}$. Lane $\mathrm{M}$ is the molecular weight size marker. 


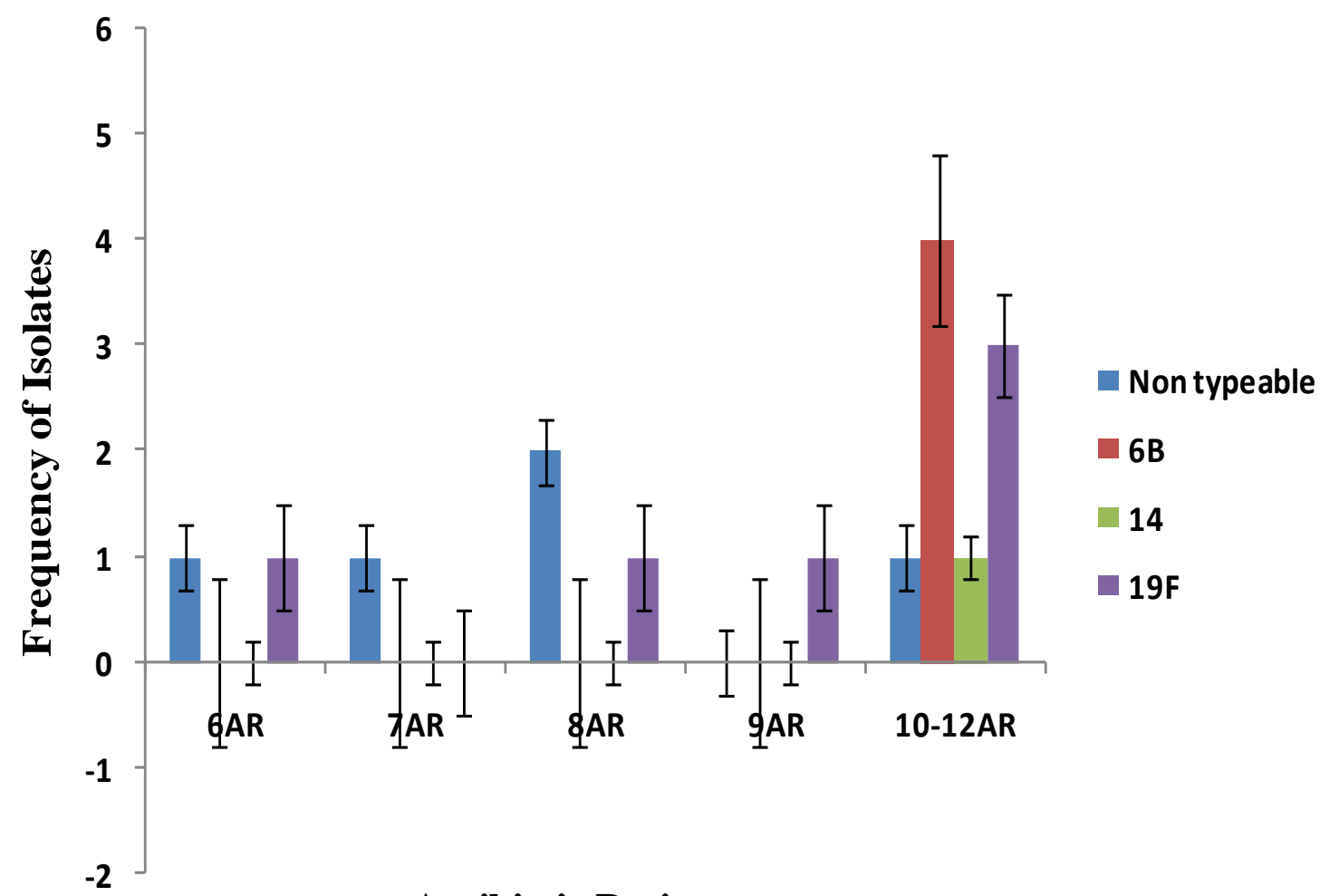

Antibiotic Resistance

(AR)

Figure 2: Serotypes and antibiotic resistance pattern of the isolates.

\section{DISCUSSION}

The study considered the antibiotic resistance and the serotypes of $S$. pneumoniae isolated from hospitalised children and determined the relationship between serotype distribution and antibiotic susceptibility. In this present study, the encapsulated $S$. pneumoniae identified were all resistant to penicillin and were multi-drug resistant. The findings reported by previous authors (Falade et al., 2009; Iwalokun et al., 2012) with the result obtained from this work have demonstrated changing trend in antibiotic susceptibility among the circulating serotypes of $S$. pneumoniae, in Nigeria. A gradual increase has been observed in resistance level among antibiotics that were initially effective against the organism.

It has been reported that patterns of change in serotype distribution varies among countries and regions (Hecini-Hannachi et al.,
2014; Huang et al., 2015). Serotype 14 has been described as one of the most common serotype causing invasive pneumococcal disease in children less than five years old children (Imöhl et al., 2010, Hecini-Hannachi et al., 2014). However, in studies on $S$. pneumoniae serotypes distribution in Nigeria there has been no known report of serotype 14 (Falade et al., 2009; Adetifa et al., 2012; Iwalokun et al., 2012). In this present study the only serotype 14 S. pneumoniae detected was resistant to erythromycin, tetracycline and the $\beta$-lactam antibiotics. Studies have shown that serotype 14 is frequently resistant to erythromycin (Clarke, 2006; Ihekweazu et al., 2007).

Apart from the serotype $14 \quad S$. pneumoniae strains identified, two other distinct serotypes $6 \mathrm{~B}$ and $19 \mathrm{~F}$ were also detected in this study. Serotype $19 \mathrm{~F}$ is the most predominant and correlates with recent 
study in China on serotype distribution in children (Huang et al., 2015). All the serotypes including the non-typable strains were multi-antibiotic resistant and this agrees with the report of Apansia et al. (2015). The isolates were highly resistant to the $\beta$-lactams antibiotics, tetracycline, cotrimoxazole and erythromycin, but low resistance was observed to gentamycin and ofloxacin. In a hospital-based study conducted in Ilorin, Nigeria in 2002, Akanbi et al. (2004) reported the recovery of $S$. pneumoniae isolates that were resistant to all tested antibiotics, including penicillin, erythromycin and ceftriaxone. The high multi-drug resistance observed in the isolates emphasises the need for surveillance. In addition, early and strict compliance to vaccine regimen will ensure protection against pneumococcal infection. Also appropriate antibiotics use has been suggested will address antibiotic resistance in S. pneumoniae (Gertz et al., 2010).

Pneumococcal serotypes vary in their likelihood of carriage, invasive potential, and disease severity which may be related to resistance (Ramdani-Bouguessa and Rahal, 2003). It has been posited that factors that alter serotype distribution may influence the prevalence of antibiotic resistance and cocolonization may also increase the likelihood of exchange of genes causing mutation that may lead to acquisition of resistance (Song et al., 2012). However, further study with large number of isolates and varied serotype is suggested since isolates size and serotypes analysed in this study is small.

\section{Conclusion}

The study provides important baseline data for continued surveillance of antibiotic resistance and serotype changes in this population that will assist immensely in future preventive and treatment strategies.

\section{COMPETING INTERESTS}

The authors declare that they have no competing interest.

\section{AUTHORS' CONTRIBUTIONS}

This work was conducted in collaborations between all the authors.

\section{ACKNOWLEDGEMENTS}

The authors are grateful to members of staff of the Mother and Child Hospital Akure, Nigeria for their kind support during sample collection.

\section{REFERENCES}

Adetifa IM, Antonio M, Okoromah CA, Ebruke C, Inem V, Nsekpong D, Bojang A, Adegbola RA. 2012. Pre-vaccination nasopharyngeal pneumococcal carriage in a Nigerian population: epidemiology and population biology. PLoS One 7(1): e30548.

DOI:10.1371/journal.pone.0030548.

Akanbi II, Taiwo AA, Babatunde SS, Onile SK, Abdulraheem IS. 2004. Antibiotic susceptibility pattern of Streptococcus pneumoniae in Ilorin, Nigeria. Afr. J. Clin. Exper. Microbiol., 5: 173 - 176.

Apansia JN, Okamo B, Mshana SE, Hokororo A, Mushi MF, Mirambo MM, Kidenya BR. 2015. Factors associated with colonization of Streptococcus pneumoniae among under-fives attending reproductive and child health clinics in Mwanza city, Tanzania. Tanz. J. Health Res., $17(1)$ : DOI:10.4314/thrb.v17i1.1

Barocchi MA, Ries J, Zogaj X, Hemsley C, Albiger B, Kanth A, Dahlberg S, Fernebro J, Moschioni M, Masignani V, Hultenby K, Taddei AR, Beiter K, Wartha F, von Euler A, Covacci A, Holden DW, Normark S, Rappuoli R, Henriques-Normark B. 2006. A pneumococcal pilus influences virulence and host inflammatory responses. Proc Natl Acad Sci, 103(8): 2857 - 2862.

Beekmann SE, Heilmann KP, Richter SS, Garcia-de-Lomas J, Doern GV. 2005. Antimicrobial resistance in Streptococcus pneumoniae, Haemophilus influenzae, Moraxella catarrhalis and group A beta-haemolytic streptococci in 2002-2003, results of the 
multinational GRASP Surveillance Program. Int. J. Antimicrob Agents., 25: 148-156.

Centre for Disease Control and PreventionCDC 2011. Laboratory methods for the diagnosis of Meningitis caused by Neisseria meningitides, Streptococcus pneumoniae and Haemophilus influenzae. USA.

Clarke SC. 2006. Control of pneumococcal disease in the United Kingdom-the start of a new era. J. Med. Microbiol., 55: 975-980.

Clinical and Laboratory Standards Institute. 2013. Performance standards for antimicrobial susceptibility testing; Twenty-Third Informational Supplement Approved standard. M100-S23. PA, USA.

Falade AG, Lagunju IA, Bakare RA, Odekanmi AA, Adegbola RA. 2009. Invasive pneumococcal disease in children aged, 5 years admitted to 3 urban hospitals in Ibadan, Nigeria. Clin. Infect. Dis., $\quad \mathbf{4 8}(2)$ : S190-196. DOI: $10.1086 / 596500$

Gant CM, Rosingh AW, López Hontangas JL, van der Heijden M, González-Morán F, Bijlsma JJ, Canton E, RedMiva (Network of Microbiological Vigilance of Comunidad Valencian). 2012. Serotype distribution and antimicrobial resistance of invasive pneumococcal disease strains in the Comunidad Valenciana, Spain, during the winter of 2009-2010: low PCV7 coverage and high levofloxacin resistance. Antimicrob. Agents Chemother., 56(9): 4988-4989. DOI: 10.1128/AAC.01201-12

Gertz RE Jr, Li Z, Pimenta FC, Jackson D, Juni BA, Lynfield R, Jorgesen JH, Carvalho Mda G, Beall BW, Active Bacterial Core Surveillance Team. 2010. Increased penicillin non-susceptibility of non-vaccine serotype invasive pneumococci other than serotypes 19A and $6 \mathrm{~A}$ in post 7-valent conjugate vaccine era. J. infect. Dis., 201: 770-775.

Hackel M, Lascols C, Bouchillon S, Hilton B, Morgenstern D, Purdy J. 2013. Serotype prevalence and antibiotic resistance in Streptococcus pneumoniae clinical isolates among global populations. Vaccine, 31(42): 4881-4887. DOI:10.1016/j.vaccine.2013.07.054

Hausdorff WP, Bryant J, Paradiso PR, Siber GR. 2000. Which pneumococcal serogroups cause the most invasive disease: implications for conjugate vaccine formulation and use, part I. Clin. Infect. Dis., 30: 100 - 121.

Hecini-Hannachi A, Bentchouala C, Lezzar A, Belabed K, Laouar H, Smati F. 2014. Serotypes and antimicrobial resistance of invasive Streptococcus pneumoniae isolates from East Algeria (2005-2011). Afr. J. Microb. Res., 8(2):167-177. DOI: 10.5897/AJMR2013,5833

Henriques-Normark B, Tuomanen EI. 2013. The pneumococcus: epidemiology, microbiology, and pathogenesis. Cold Spring Harb. Perspect. Med., 3(7): a010215. DOI: 10.1101/cshperspect.a010215.

Huang S, Liu X, Lao W, Zeng S, Liang H, Zhong R, Dai X, Wu X, Li H, Yao Y. 2015. Serotype distribution and antibiotic resistance of Streptococcus pneumoniae isolates collected at a Chinese hospital from 2011 to 2013. BMC Infect. Dis., 15: 312. DOI: 10.1186/s12879-015-1042-5

Ihekweazu CA, Dance DA, Pebody R, George RC, Smith MD, Waight P, Christensen H, Cartwright KA, Stuart JM, South West Pneumococcus Study Group. 2008. Trends in incidence of pneumococcal disease before introduction of conjugate vaccine: South West England, 1996-2005. Epidemiol. Infect., 136(8): 1096-1102. DOI:10.1017/S0950268807009715

Imöhl M, Reinert RR, van der Linden M. 2010. Regional differences in serotype distribution, pneumococcal vaccine coverage and antimicrobial resistance of invasive pneumococcal disease among German federal states. Int. J. Med. Microbiol., $\quad$ 300(4): $\quad 237-247$. DOI:10.1016/j.ijmm.2009.05.005. 
Iwalokun BA, Fowora M, Akinloye O, Oluwadun A, Antonio M, Adegbola RA. 2012. A retrospective study of clinical Streptococcus pneumoniae isolates from four health facilities in South-West Nigeria. Int. J. Med. Medical Sci., 4(8): 160-170. DOI:10.58971/IJMMS12.054

Kadioglu A, Cuppone AM, Trappetti C, List T, Spreafico A, Pozzi G, Andrew PW, Oggioni MR. 2011. Sex-based differences in susceptibility to respiratory and systemic pneumococcal disease in mice. J. Infect. Dis., 204: 1971- 1979. DOI; 10.1093/infdis/jir657

Link-Gelles R, Thomas A, Lynfield R, Petit S, Schaffner W, Harrison L, Farley MM, Aragon D, Niicols M, Kirley PD, ZanskyS, Jorgensen J, Juni BA, Jackson D, Moore MR, Lipsitch M. 2013. Geographic and temporal trends in antimicrobial non-susceptibility in Streptococcus pneumoniae in the post vaccine era in the United States. $J$. Infect. Dis., 208(8): 1266-1273. DOI:10.1093/infdis/jit315

Nuorti JP, Whitney CG, Centers for Disease Control and Prevention (CDC). 2010. Prevention of pneumococcal disease among infants and children-use of 13valent pneumococcal conjugate vaccine and 23-valent pneumococcal polysaccharide vaccine: recommendations of the Advisory Committee on Immunization Practices (ACIP). MMWR Recomm Rep., 10;59 (RR-11): $1-18$.

Obaro S, Lawson L, Essen U, Ibrahim K, Brooks K, Otuneye A, Shetima D, Ahmed P, Ajose T, Olugbile M, Idiong $\mathrm{D}$, Ogundeji D, Ochigbo C, Olanipekun G, Khalife W, Adegbola R. 2011. Community acquired bacteremia in young children from central Nigeria- a pilot study. BMC Infect. Dis., 11: 137. DOI: 10.1186/1471-2334-11-137

O'Brien KL, Wolfson LJ, Watt JP, Henkle E, Deloria-Knoll M, McCall N, Lee E,
Mulholland K, Levine OS, Cherian T, Hib, Pneumococcal Global Burden of Disease Study Team. 2009. Burden of disease caused by Streptococcus pneumoniae in children younger than 5 years: global estimates. Lancet, 374: 893-902. DOI: $10.1016 / \mathrm{Sd} 140-$ 6736(09)61204-6

Park IH, Pritchard DG, Cartee R, Brandao A, Brandileone MC, Nahm MH. 2007. Discovery of a new capsular serotype (6C) within serogroup 6 of Streptococcus pneumoniae. J. Clin. Microbiol., 45: 1225-1233.

Pichon B, Ladhani SN, Slack MP, SegondsPichon A, Andrews NJ, Waight PA, Miller E, George R. 2013. Changes in the molecular epidemiology of Streptococcus pneumoniae causing meningitis following the introduction of pneumococcal conjugate vaccination in England and Wales. J. Clin. Microbiol., 51(3): 820-827. DOI:10.1128/JCM.01917-12

Ramdani-Bouguessa N, Rahal K. 2003. Serotype Distribution and Antimicrobial Resistance of Streptococcus pneumoniae Isolated in Algiers, Algeria. Antimicrob. Agents Chemother., 47(2): $824-826$.

Ruoff K, Whiley RA, Beighton D. 2003. Streptococcus. In Manual of Clinical Microbiology (8th edn, vol. 1), Murray PR, Baron EJ, Jorgensen JH, Pfaller MA, Yolken RH (eds). ASM Press: Washington, DC; 405 - 421.

Shouval DS, Greenberg D, Givon-Lavi N, Porat N, Dagan R. 2006. Site-specific disease potential of individual Streptococcus pneumoniae serotypes in pediatric invasive disease, acute otitis media and acute conjunctivitis. Pediatr. Infect. Dis. J. 25: $602-607$.

Song JH, Dagan R, Klugman KP, Fritzell B. 2012. The relationship between pneumococcal serotypes and antibiotic resistance Vaccine. 30(17): 2728-2737. DOI: $\quad$ 10.1016/j.vaccine.2012.01.091 